\title{
Traceability of Food Products in Global Gastronomic Tourism*
}

\author{
Antonella Reitano ${ }^{* *}$, Marco Fazio ${ }^{* * *}$, David W. Taylor ${ }^{* * * *}$
}

\begin{abstract}
The role of wine and food products in tourism is multiform and complex. Throughout human history, food has not just been a means of subsistence, but has often become an element for authentic experience, socialising and hospitality. Within the context of global tourism, enogastronomy determines the qualitative level of the offer. It can be said that nowadays the package of goods destined for tourism is enriched by a new attribute, that of quality food, which has taken on a social aspect: more and more tourists travel to specific destinations because of good food. Traceability and protection brands are, without doubt, indicators for measuring the quality of food. The propensity to purchase and consume "traced" food were analysed with specific reference to olive oil. Data were collected through a $500 \mathrm{~Hz}$ binocular remote eye-tracking system and analysed with SPSS software.
\end{abstract}

Keywords: Traceability; Eye Tracking System; Consumer Behaviour; Protection Brands; Olive Oil; Global Tourism; Enogastronomy

\section{Global Tourism and Gastronomic Products}

The development of local products in rural areas is not to be seen exclusively as support for the productive spirit of such areas, but rather has to be interpreted as part of a greater local development plan, which aims at unifying different economic and productive components so as to develop the links upon which a district's economy is based. Such links reciprocally reinforce and can be activated at local level through a systematic development of rural economy, and a highly representative example of this is the interdependence which is created between local products and tourism in specific areas (Bencivenga et al., 2016). Enogastronomic experiences can contribute to the creation, improvement or reinforcing of the genius loci and for some can become primary elements in choosing a tourist destination (Hede, 2008).

In the context of global tourism (Salama, 2015; Scott \& Gössling, 2015; Bellini \& Brondoni, 2016; Salazar, 2016) enogastronomy helps determine the quality level of

\footnotetext{
* The Authors: A. Reitano $\S \S 1,3,3.4,3.5,4$, M. Fazio $\S \S 3.1,3.2,3.3$, D. W. Taylor $\S 2$

** Associate Professor of Marketing, University of Calabria (a.reitano@unical.it)

*** Assistant Professor of Marketing, University of Calabria (ing.marcofazio@gmail.com)

**** Principal Lecturer of Management, Manchester Metropolitan University (d.w.taylor@mmu.ac.uk)
} 
an offer. Since the beginning of the 1990s, holidays have come to represent a need for almost the entire population of post-industrial countries. The increasingly diversified requests reflect a demand for low cost products, preferably differentiated, centred on short holidays, in various periods of the year, at far away, little known destinations which are nearly always reached by air; a new form of tourism known as global or postmodern tourism (Leed, 1992).

Global tourism is, then, a successive stage to the 'modern'. It is characterised not only by high percentages of people who practice tourism, but even more by the tourist destinations to be discovered. It is no longer the destination that makes the difference, but the experience that one can have. More and more tourists are looking for not just a natural or artistic setting, sport or recreational structures, but also numerous different ways to experience (Pine \& Gilmore, 1999) them, often as a protagonist. The tourist destination is, then, a sort of stage on which the traveller chooses a role to interpret. Such a form of tourism has been encouraged over recent years by a change of rules brought about by the sharing economy, as a technological-economic phenomenon promoted by the development in the ICT industry (Salvioni, 2016).

The range of goods destined for tourism has been enriched with a new aspect, that of quality food and drink. These have a value of a strictly economic nature which is linked to an important element of a social nature: since the origin of mankind, food has been one of, if not the most important, elements on which interpersonal relations have developed.

In today's dynamic and competitive contexts of excess supply, the certifying of food quality is ascertained through traceability and protection brands. Therefore, attention is no longer given simply to the brand (Olson \& Jacoby, 1972), price, advertising, retailer brand and country of origin (Zeithaml, 1988; Teas \& Agarwal, 2000), but rather purchasers and consumers are looking more and more at protection brands (Agostino \& Trivieri, 2014) and traceability to certify food and drink quality.

Market globalisation (Brondoni \& Pironti, 2015) and the increasing threats to food safety have contributed to undermining consumer confidence in food producers, rendering food traceability a potential solution to these major issues.

The European Union currently protects top quality farm products, since this quality undeniably helps producers to protect their territorial identity and increases their profitability and competitiveness in an increasingly globalised market (Reitano \& Fazio, 2014). Quality is guaranteed by the compulsory traceability requirement (EC Regulation No. 178/2002), as well as by collective protection brand systems (Protected Designation of Origin - PDO, Protected Geographical Indication - PGI and Specificity Certificate or Traditional Speciality Guaranteed TSG), which are general frameworks of rules through which agro-alimentary products can be registered as collective brands. The importance of traceability can be assessed in terms of easily and quickly retrieved, clear and reliable information on a specific product, at all stages of the production process, which can help in the buyer's decision-making process (Bhatt et al., 2013). Despite the importance of quality certification and geographic denominations within the EU quality protection framework, the impact of quality certification on consumer choice still needs to be empirically investigated (Josling, 2006; Bramley et al., 2009). Based on these 
assumptions, the aim of this work is to analyse whether there is a positive association between brand protection and purchasing behaviour. Moreover, the visual impact of brand protection on olive oil labels is investigated, along with the unconscious and analytical reactions of consumers classified by age groups.

Most purchases are not the result of a careful analysis of the available information and a consequent logical assumption; they are frequently linked to irrational behaviour (Fitzsimons et al., 2002). Choosing food is also a complex phenomenon depending on several related factors (Köster, 2009).

Numerous studies show that consumers make their choices by focusing on a series of elements and features which help customers maximise the advantages and minimise the losses involved in a purchase (Elrod et al., 2004). However, consumers have a limited capacity to process information and are primarily led by intuition (Milosavljevic \& Cerf, 2008), specifically in the case of complex choices (Kahneman, 2003). Moreover, research points out that, in many cases, purchasing decisions are made unconsciously (Fitzsimons et al., 2002) and are driven by two different approaches (Stanovich \& West, 2000). The first is an experiential approach based on an emotional and perceptive drive, characterised by fast and effortless answers, as well as by automatic and associative processes (Lieberman, 2000). The second approach is more rational, decision-based and analytical and involves a slower, more responsible process (Stanovich \& West, 2000). Our minds very often go through an unconscious storm of contrasting emotions when we have to make a decision on what to buy and whether a purchase is needed. The prevalence of positive emotions over negative emotions very often leads to purchasing decisions. Sometimes customers do not know exactly what to buy and cognitive answers are often very different from the emotional responses that leading to purchasing and consumption behaviour. Today in markets which present a great range of products (Lambin, 2014), it is very often the product packaging, shelf displays and quality certifications (such as brand protection) that increase product visibility, which, in turn, influences customers to perceive of high quality and triggers unconscious mechanisms that lead to purchasing. Therefore, physiological observations of consumers can be employed to understand their behaviour or infer sensations, moods and emotions that cannot always be detected through the administration of simple questionnaires (Reitano \& Calomino, 2008). The body cannot lie and consequently biometric measurements, such as eye tracking and oculometry, can be adopted in tandem with the tools traditionally used to obtain information on consumers.

\section{Purchasing Behaviour Regarding Traced Food Products}

Market expansion, the collapse of barriers and geographical boundaries and the consequent threats to food safety have jeopardised consumer confidence in producers, thus making food traceability a potential solution to the issues dealt with in this study (Reitano \& Fazio, 2014). 'Traceability' and 'tracking' are two specular processes, often misused as synonyms. It is not by chance that, in English, the word tracking has evolved from the Italian word 'tracciabilità' and tracing from 'rintracciabilità'. In the first case, it is important to establish what kind of 
information should 'leave a track' along the process, considering its importance as an instrument of product control and identification in its course from the field to the table. Instead the word 'rintracciabilità' identifies such 'tracks': the two processes are highly intertwined (Reitano \& Fazio, 2015).

Traceability gives important marketing leverage in so far as it enriches the bundle of product characteristics, supporting increases in retail prices, defining distribution channels and ensuring corporate/brand identity. Identity is considered in terms of reputation, the extent to which consumers memorise, remember and recognise a given brand in relation to its name or to the features through which it is represented, and its product image, derive from a series of factors that can be linked to product features and generate positive or negative opinions (Reitano \& Fazio, 2015).

As for analysis of the elements indicated on food labels, several studies have investigated their impact on consumers. For instance, nutritional information is reported on labels with the aim of informing consumers about food quality and to induce them to buy healthy food (Cowburn \& Stockley, 2005). However, most people tend to ignore such information when buying a product, since it sometimes cannot be easily understood (Grunert \& Wills, 2007; Grunert et al., 2010; Roberto et al., 2012). For this reason, nutrition labels have been introduced to complete traditional labels according to the traffic light system, indicating guidelines for daily consumption in terms of nutritional elements. This system is simple, easy to understand and, above all, it is able to attract consumers' visual attention (Jones \& Richardson, 2007; Grunert et al., 2010; van Herpen et al., 2012).

Several studies on this topic have demonstrated that the traffic light system easily grabs consumers' attention and facilitates the understanding of nutritional information (Ares et al., 2012; Antúnez et al., 2013). Based on the results of such research, this study aims to analyse the visual impact on consumers of protection brands on olive oil labels and to assess whether consumers' attention is attracted by such brands. Since there are several collective brands in terms of geographical indication, and each is represented by a different graphic image and by a specific caption on the label, it is interesting to assess whether they generate the same impact on consumers or if factors such as age, consumption habits and behaviour (visual vs rational) may have an influence.

\section{The Research}

The purpose of this research is to explore the behaviour of tourists with regard food consumption. Our interest lies specifically on understanding if and how much consumers purchasing tourist products and services prefer quality food. For this reason, attention is focused on olive oil, a basic food par excellence, as well as a key element in the Mediterranean diet, which in November 2010 was recognised as an Intangible Cultural Heritage of Humanity by UNESCO. Olive oil is highly differentiated, so this study is focused on traced oil as certified by the protection brands of the European Community to better understand how traceability and protection brands influence purchasing and consumption decisions.

Firstly, the research aimed at investigating consumers' knowledge of the notions of traceability and brand protection in order to understand whether there is a 
propensity to buy traced products and if traceability is perceived of by consumers as a competitive advantage of the product. The survey also showed that the majority of the consumers know about protection brands but do not always correctly associate the picture with the designation. In this regard, among the interviewed, those mainly attracted by the red icon gave greater attention to the label, whereas, those mainly attracted by the blue icon gave less attention to the different details of the label. Consumers associate a higher level of quality with the traced products: they seek traceability through the protection brands or, more often, through a personal tracking mechanism which consists of being supplied by a trusted farmer. Such data was collected through the administration of a questionnaire to consumers. Moreover, the research investigated and assessed the presence of potential unconscious mechanisms triggered by seeing the protection brand on a label. More precisely, the visual impact of protection brands on olive oil was observed and it was investigated whether such brands are able to attract consumers' visual attention (Henderson, 2017). Furthermore, since there are several collective brands protected by geographical indications on labels, and each is represented by a different image, as well as a specific caption, it is interesting to verify if they have the same impact on consumers or if other factors, such as age, can have an influence on the final decision. Formally, the hypothesis is the following:

$H_{1}$ : Is there a positive association between gaze, area of interest and age groups? (statistically different averages);

consequently, the null hypothesis is the following:

\section{$H_{0}$ : Same average number (no association between gaze and age groups).}

In order to verify such hypothesis, data was collected through an eye-tracking system and subsequently analysed from a statistical point of view by using SPSS software. Therefore, the research was carried out in a laboratory so as to guide the participants' attention towards the investigated elements, without the participants' being influenced by environmental (Gijsbrechts et. al, 2003; Dijksterhuis et al., 2005; Garrido-Morgado \& González-Benito, 2015) and/or personal (Foxall \& Bhate, 1993; Seitz, 2007; Zhang et al., 2009) factors as would happen in any retail shop.

\subsection{Participants}

The research was carried out over a sample of 42 individuals (60\% men). The sample was made up of university students and workers, with an age range between 18 and 65. For reasons of analysis, the sample was divided into two groups (through the calculation of the median) according to age. The '18-29 year-old' group and the 'over 30 year-old' group. Consumption habits for the latter were supposed to be different when compared with young university students. Of the total number of individuals, the 'over 30-year old' group represented 55\% of the sample, and the students represent half of the sample. 


\subsection{Visual Stimuli}

Through the eye-tracking system, it is possible to identify both the 'length' and the 'frequency' of gazes by interviewed individuals at the various parts of the pictures shown to them (Lahey \& Oxley, 2016). The gaze maps obtained for each interviewee were the result of the gazes at the pictures. The research focused on the projection of seven different pictures showing a bottle of olive oil, projected for fifteen seconds with each picture then followed by an interval of six seconds during which a neutral background was projected. Each gaze was numbered on the basis of the sequence of gazes at a specific part of the picture.

Besides the projection of pictures with a record of the individuals' gazes and saccades, the experiment included a set of questions concerning the interviewees' awareness of the brands, their perception of higher quality, and their willingness to pay a higher price for some products. Two bottles of extra virgin olive oil were used for the research. One had a PGI (Protected Geographical Indication) brand, while the second had a PDO (Protected Designation of Origin) brand. The images of both bottles were projected in the same picture. The choice of the bottle was not random, but closely related to the objectives of the research; plain and simple packaging do not distract the observer. Furthermore, the label is characterised by some elements useful for the research. The label is organised into sections: starting from the top, there is the brand of the producer, the picture of an old country mill, the wording of the type of oil (i.e. extra virgin olive oil), the words PGI/PDO, the name of the oil and, finally the graphic icon of the protection brand (on blue background if PGI oil, on red background if PDO oil). The label contains several information, but this research was focused on two different Areas Of Interest (AOI):

- $\quad$ AOI 1: word PGI/PDO;

- $\quad$ AOI 2: graphic icon of the protection brand (PGI/PDO);

\subsection{Instruments and Equipment}

The study was carried out by means of a $500 \mathrm{~Hz}$ binocular remote eye-tracking system. Through such a system, it was possible to assess both the 'time' and the 'frequency' of the gaze of individuals at the different areas of the images shown. The maps of the gaze obtained for each interviewee, were the result of their gaze at projected images. The length of the projection was 15 seconds. Statistical analysis was carried out by means of SPSS software.

\subsection{Analysis of Data}

The gaze at each area of interest was registered from the projection of the picture of the two bottles with brand protection. Since the picture shows two different olive oil bottles contemporaneously, one with the DPO brand and the other with the PGI brand, to analyse data, an average of gazes at the area of interest was considered.

The average gazes at the two bottles were compared for areas of interest 1 and 2; the AOI 1 is characterised by the caption DPO/PGI on the label, while AOI 2 is characterised by the icon. The analysis of data was carried out through a 
comparison of the averages of independent samples (Independent sample t-Test), after having used SPSS software, and by considering the qualitative variable 'age' for the two groups and the quantitative variable "number of gazes" at the areas of interest considered.

Table 1: Groups Statistics

\begin{tabular}{|c|c|c|c|c|c|}
\hline & Age & $\mathrm{N}$ & Mean & Std. Deviation & $\begin{array}{c}\text { Std. Error } \\
\text { Mean }\end{array}$ \\
\hline \multirow{2}{*}{ AOI 1 } & $18-29$ & 19 & 4,974 & 2,5899 &, 5942 \\
\cline { 2 - 6 } & over 30 & 23 & 6,804 & 3,0404 &, 6340 \\
\hline \multirow{2}{*}{ AOI 2 } & $18-29$ & 19 & 7,395 & 6,8730 & 1,5768 \\
\cline { 2 - 6 } & over 30 & 23 & 3,913 & 1,8808 &, 3922 \\
\hline
\end{tabular}

Source: Authors' Elaboration

Table 2: Independent Sample Test

\begin{tabular}{|c|c|c|c|c|c|c|c|c|c|c|}
\hline \multicolumn{11}{|c|}{ Independent samples test } \\
\hline & & \multicolumn{2}{|c|}{$\begin{array}{c}\text { Levene's test for } \\
\text { equality of } \\
\text { variances }\end{array}$} & \multicolumn{7}{|c|}{ t-Test for equality of means } \\
\hline & & \multirow[t]{2}{*}{$\mathrm{F}$} & \multirow[t]{2}{*}{ Sig. } & \multirow[t]{2}{*}{$\mathrm{T}$} & \multirow[t]{2}{*}{ df } & \multirow{2}{*}{$\begin{array}{l}\text { Sig. } \\
(2- \\
\text { tailed })\end{array}$} & \multirow[t]{2}{*}{$\begin{array}{c}\text { Mean } \\
\text { Difference }\end{array}$} & \multirow[t]{2}{*}{$\begin{array}{l}\text { Std. Error } \\
\text { Difference }\end{array}$} & \multicolumn{2}{|c|}{$\begin{array}{c}95 \% \text { Confidence } \\
\text { Interval of the } \\
\text { difference }\end{array}$} \\
\hline & & & & & & & & & Lower & Upper \\
\hline \multirow{2}{*}{$\overline{0}$} & $\begin{array}{c}\text { Equal } \\
\text { variances } \\
\text { assumed }\end{array}$ & , 166 & ,686 & $-2,074$ & 40 &, 045 & $-1,8307$ &, 8825 & $-3,6142$ &,- 0471 \\
\hline & $\begin{array}{c}\text { Equal } \\
\text { variances } \\
\text { not } \\
\text { assumed }\end{array}$ & & & $-2,107$ & 39,950 &, 041 & $-1,8307$ & ,8689 & $-3,5868$ &,- 0745 \\
\hline \multirow{2}{*}{$\stackrel{2}{0}$} & $\begin{array}{c}\text { Equal } \\
\text { variances } \\
\text { assumed }\end{array}$ & 10,822 & ,002 & 2,332 & 40 & 025 & 3,4817 & 1,4933 & ,4636 & 6,4998 \\
\hline & $\begin{array}{c}\text { Equal } \\
\text { variances } \\
\text { not } \\
\text { assumed }\end{array}$ & & & 2,143 & 20,233 &, 044 & 3,4817 & 1,6248 & 0949 & 6,8685 \\
\hline
\end{tabular}

Source: Authors' Elaboration

As for AIO 1, the test on variance homogeneity provides an insignificant $p$ value:

$p=.686>.05$

therefore, according to Levene's test the assumption is verified and the null hypothesis can be accepted. By considering the results of the t-Test, by assuming equal variances, $p$-value characterising the value of statistical datum $t$ is lower than 0.05 : 
$p=.045<.05$

therefore, the null hypothesis (equal averages) is rejected; averages differ from each other. The null hypothesis is also rejected for the AOI 2: in this case the hypothesis that two variances are equal is rejected by Levene's test ( $p$-value lower than 0.05):

$$
p=.002<.05
$$

By considering the results of the t-Test, and in this case, equal variances are not assumed, the $p$-value is again lower than 0.05 :

$$
p=.044<0.05
$$

therefore, the null hypothesis is again rejected. To conclude, the $\mathrm{H}_{1}$ hypothesis can be accepted for both areas of interest.

The following images show the heatmaps indicating the average gaze for graphic stimulus considered for each age group.

Figure 1: Heatmaps with the Average Gaze for the 18-29 Age Group and Over 30 Age Group

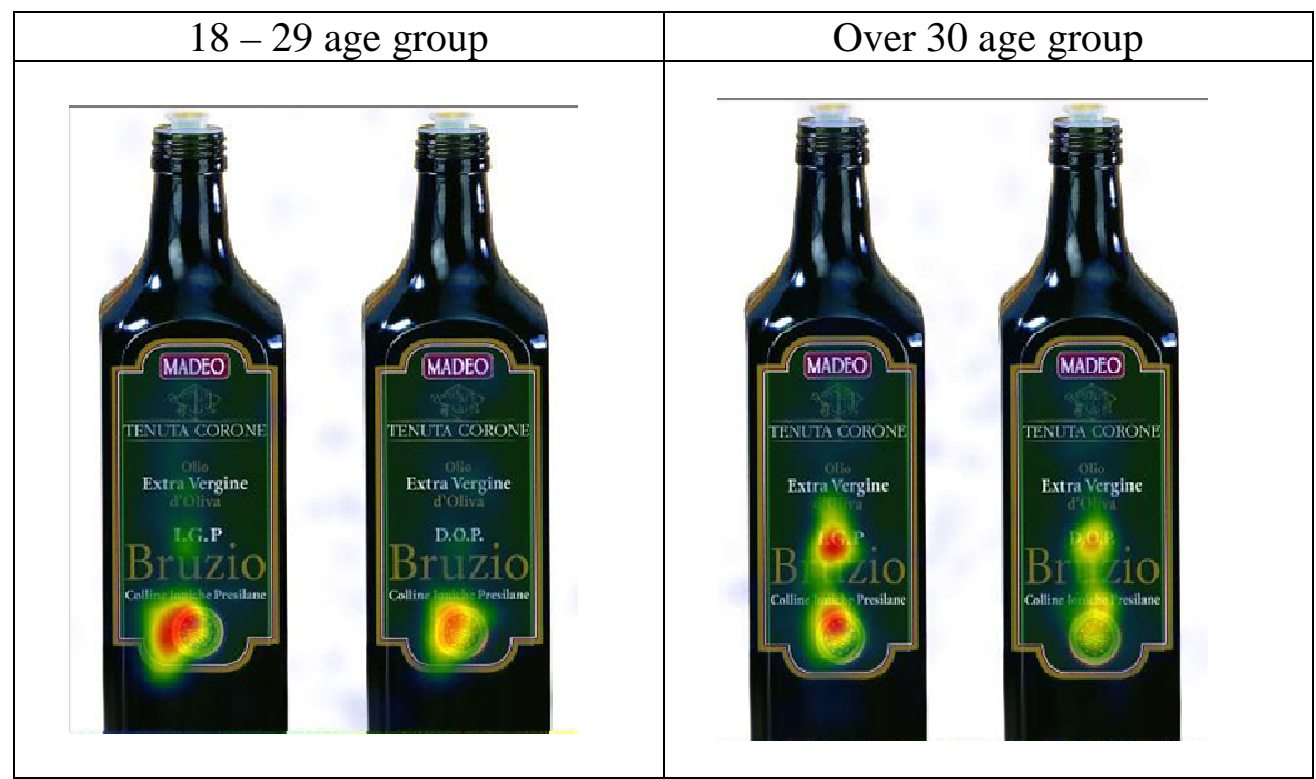

The heatmaps of the two groups visually highlight the hypothesised, and then statistically verified, differences.

It can be clearly seen that younger people focus their gaze on the graphic icon, neglecting the other elements on the bottle. Older people, though, spread their attention almost equally between the graphic icon and the wording of the same information included in the graphic icon. 


\subsection{Discussion}

By analysing eye tracks and, more specifically, the number of gazes at the graphic stimulus, it is evident that, on average, if the sample is sorted into two age groups (18-29 and over 30), the groups display different behaviour. Young people are more attracted by graphic details (the DPO and PGI icon), while the over-30 group is generally more reflective, they tend to observe the whole label and give to attention to both the icon and other features.

At this point an explanation relating to generational differences can be found: digital natives are more attracted by graphic icons because these are more similar to information in digital form which they are accustomed to; elder people, born, educated and shaped within a context of analogical information, continue to give more attention to and show an aptitude for analogical information, dividing their gaze between graphic icon and the wording PDO and PGI.

In general, regardless of the reference group, heatmaps are characterised by a greater observation of the bottle on the left of the image, confirming what was shown by the F-pattern model (Pernice et al., 2014), according to which people, especially westerners, who write from left to right, almost invariably read a text or look at an image by following a capital $\mathrm{F}$ pattern. Consequently, it is obvious that gazes at the bottle on the left are quantitatively more numerous.

Of the all information included on the label, attention is predominantly given to the protection brand, both in graphic and analogical forms, neglecting other items of information. This demonstrates that the observers' attention centres on the quality of the product.

$\square$ The Bratislava Case. Since 2000, Bratislava has undergone a marked process of economic development, of which tourism is an important aspect. Given the favourable geographical position $(60 \mathrm{Km}$ from Vienna and 200 from Budapest), it is often part of both national and international tours for mass tourism. The old town comes alive around 10 o'clock every morning, livened up by thousands of tourists until the early hours. The old town is completely pedestrian, since traffic is forbidden even to taxis and buses. Great attention was given to the promotion of architectural heritage: Bratislava castle; St. Martin's Cathedral; the Blue Church; Grassalkovich Palace; Primate's Palace; St. Michael's Gate; Hviezdoslav Square. Over recent years, Bratislava has been enriched with various bronze statues, highly appreciated by tourists: the Napoleonic soldier, Čumil appearing from a manhole; Schöner Náci, also known as Bela Ignaz. In Hviezdoslav Square, stands a statue dedicated to Andersen, who may have written "The Little Match Girl" in Bratislava or was inspired by the fire at Devin Castle. In fact, although Andersen travelled a lot, and wrote a lot, there is no documented proof of a link between the fairy tale and Bratislava (Olsen \& Topsфe-Jensen (ed.), 1973). Street artists are rare, even at weekends. A construction of great value is the Danubiana Meulensteen Art Museum, inaugurated in September 2000, in a picturesque spot, a peninsula reaching out into the Danube, about $15 \mathrm{~km}$ from the city 
centre. The museum can be reached in 90 minutes by boat from the centre of Bratislava and, therefore, is the ideal destination for those who are looking for a pleasant, quiet day between nature and art. The city pays notable attention to tourists: streets are very clean and, on muggy days, special devices micronise water, so helping combat the humidity.A stay in Bratislava is a very agreeable experience (Pine \& Gilmore, 1999). The old town has not lost its identity. Given the short distances, it is relaxing to visit the interesting museums, antique shops and pleasant stores selling Slovak souvenirs (including coins from the local Mint); it is easy to buy fine chocolates or the typical Mariánskolázenské Oplatky (IGP) or savour a tasty cake in a historical shop. It is not, though, easy to find quality food, be it Slovak or foreign in the old town, particularly in the streets that tourists frequent. Therefore, one gets the sensation that the tourists are the centre of attention for local and central politics: so much has been done to develop tourism, even a daring, as not demonstrated, connection between the city and one of the world's most well-known fables, as well as large public works, bridges, shopping centres with numerous restaurants and places to meet, and spots on the suggestive left bank of the Danube (Špirková, 2011). So, the tourist offer, in the old town, has been enriched and extended through the addition of various elements, but ignoring good food and, therefore, traced products. The reason could be the lack of consistency of Slovak products with protection brands. There are 36 in total, of which 8 are PDO, 11 PGI and 7 TSG. Almost $90 \%$ of all Slovak PDO products are wines. The total of Slovak products equipped with protection brands is just $1.1 \%$ of the total of European products. Moreover, it should not be forgotten that Slovakia does not count, amongst its strong points, the sort of high value, traditional, universally acknowledged and appreciated cuisine, which, instead, enriches other European tourist destinations (Pergament, 2017). With a view to the development of global tourism, the importance of quality enogastronomy for some consumers, attentive to protection brands and, so, tending to look carefully at labels, should not be disregarded (Nikolova \& Inman, 2015).

\section{Conclusions}

The eye-tracking systems show interesting elements to better understand preferences when purchasing. In particular, the survey carried out showed that, when looking at a bottle, the consumer focuses on the protection brands and is willing to spend more to purchase products with such brands.

Different age groups exhibit interesting differences: younger people focus their attention on icon and pictures, while older people look more critically at the entire label, while also focusing greatly on the descriptions.

Therefore, whatever the age, consumers associate traced products with a higher level of quality, identifying a factor of competitiveness in the traceability. 
In line with the Butler model (Butler, 1980), according to which, factors influencing the evolution and life cycle of a tourist spot include qualitative and quantitative changes in available resources, it is necessary from a global tourism point of view that the package of goods a tourist destination offers is rich in monuments, infrastructures, services and places of leisure, as well as good food and traditional cuisine.

Quality certification of food is ensured by traceability and protection brands, and these are increasingly understood and sought by consumers of all ages.

\section{Bibliography}

Agostino, M., Trivieri, F. (2014). Geographical indication and wine exports. An empirical investigation considering the major European producers. Food Policy, (46), 22-36.

http://dx.doi.org/10.1016/j.foodpol.2014.02.002

Antúnez, L., Vidal, L., Sapolinski, A., Giménez, A., Maiche, A., Ares, G. (2013). How do design features influence consumer attention when looking for nutritional information on food labels? Results from an eye-tracking study on pan bread labels. International Journal of Food Sciences and Nutrition, 64 (5), 515-527.

http://dx.doi.org/10.3109/09637486.2012.759187

Ares, G., Giménez, A., Bruzzone, F., Antúnez, L., Sapolinski, A., Vidal, L., Maiche A. (2012). Attentional capture and understanding of nutrition labelling: A study based on response times. International Journal of Food Sciences and Nutrition, 63 (6), 679-688.

http://dx.doi.org/10.3109/09637486.2011.652598

Bellini, N., Brondoni, S. M. (2016). Ouverture de 'Global Tourism in Global Markets'. Symphonya, Emerging Issues in Management (symphonya.unimib.it), (1), 1-6.

http://dx.doi.org/10.4468/2016. 1.010uverture

Bencivenga, A., Dalterio Vollaro, P., Forte, F., Giampietro, A. M., Percoco, A. (2016). Food and wine tourism in Basilicata. Agriculture and Agricultural Science Procedia, (8), 176-185. http://dx.doi.org/10.1016/j.aaspro.2016.02.091

Bhatt, T., Buckley, G., McEntire, J.C., Lothian, P., Sterling, B., Hickey, C. (2013). Making Traceability Work across the Entire Food Supply Chain. Journal of Food Science, 78 (S2), B21B27.

http://dx.doi.org/10.1111/1750-3841.12278

Bramley, C., Bienabe, E., Kirsten, J. (2009). The economics of geographical indications: towards a conceptual framework for geographical indication research in developing countries. The Economic of Intellectual Property, 101, 109-138.

Brondoni, S. M., Pironti, M. (2015). Ouverture de 'Design Management, Product Engeneering and Global Competition. Symphonya, Emerging Issues in Management (symphonya.unimib.it), (2), 1 12.

http://dx.doi.org/10.4468/2015.2.01ouverture

Butler, R. W. (1980). The concept of a tourist area cycle of evolution: implications for management of resources. Canadian Geographer / Le Géographe canadien, XXIV (1), 5-12.

http://dx.doi.org/10.1111/j.1541-0064.1980.tb00970.x

Cowburn, G., Stockley, L. (2005). Consumer understanding and use of nutrition labelling: A systematic review. Public Health \& Nutrition, 8 (1), 21-28.

https://doi.org/10.1079/PHN2004666 
Dijksterhuis, A., Smith, P. K, van Baaren, R. B., Wigboldus, D. H. J. (2005), The Unconscious Consumer: Effects of Environment on Consumer Behavior. Journal of consumer psychology, 15 (3), 193-202.

http://dx.doi.org/10.1207/s15327663jcp1503_3

Elrod, T., Johnson, R. D., White, J. (2004). A new integrated model of noncompensatory and compensatory decision strategies. Organizational Behavior and Human Decision Process, (95), 1 19.

http://dx.doi.org/10.1016/j.obhdp.2004.06.002

Fitzsimons, G. J., Hutchinson, J. W., Williams, P., Alba, J. W., Chartrand, T. L., Huber, J., et al. (2002). Non-conscious influences on consumer choice. Marketing Letters, 13 (3), 269-279.

Foxall, G. R., Bhate, S. (1993). Cognitive Style and Personal Involvement as Explicators of Innovative Purchasing of 'Healthy' Food Brands. European Journal of Marketing, 27 (2), 5-12.

http://dx.doi.org/10.1108/03090569310026376

Garrido-Morgado, A., González-Benito, O. (2015). Merchandising at the point of sale: differential effect of end of aisle and islands. Business Research Quarterly, 18 (1), 57-67.

http://dx.doi.org/10. 1016/j.brq.2013.11.004

Gijsbrechts, E., Campo, K., Goossens, T. (2003). The impact of store flyers on store traffic and store sales: a geo-marketing approach. Journal of Retailing, 79 (1), 1-16.

http://dx.doi.org/10.1016/ S0022- 4359(03)00006-X

Grunert, K. G., Wills, J. M. (2007). A review of European research on consumer response to nutrition information on food labels. Journal of Public Health, 15 (5), 385-399.

http://link. springer.com/article/10.1007\%2Fs10389-007-0101-9

Grunert, K. G., Wills, J. M., Fernández-Celemín, L. (2010). Nutrition knowledge, and use and understanding of nutrition information on food labels among consumers in the UK. Appetite, 55 (2), 177-189. http://dx.doi.org/10.1016/j.appet.2010.05.045

Hede, A. M. (2008). Food and Wine Festivals: Stakeholders, Long-term Outcomes and Strategies for Success. C.M. Hall \& L. Sharples, (eds), Food and Wine Festivals and Events Around the World: Development, Management and Markets, Oxford: Butterworth Heinemann, 85-100.

Henderson, J. M. (2017). Gaze Control as Prediction. Trends in Cognitive Sciences, 21 (1), 15-23. http://dx.doi.org/10.1016/j.tics.2016.11.003

Jones, G., Richardson, M. (2007). An objective examination of consumer perception of nutrition information based on healthfulness ratings and eye movements. Public Health Nutrition, 10 (3), 238-244. http://dx.doi.org/10.1017/S1368980007258513

Josling, T. (2006). The War on Terroir: Geographical Indications as a Transatlantic Trade Conflict. Journal of Agricultural Economic, 57 (3), 337-363.

http://dx.doi.org/10.1111/j.1477-9552.2006.00075.x

Kahneman, D. (2003). Maps of Bounder Rationality: Psychology for Behavioral Economics. The American Economic Review, 93 (5), 1449-1475.

Köster, E. P. (2009). Diversity in the determinants of food choice: A psychological perspective. Food Quality and Preference, 20 (2), 70-82. http://dx.doi.org/10.1016/j.foodqual.2007.11.002

Lahey, J. N., Oxley, D. (2016). The Power of Eye Tracking in Economics Experiments. American Economic Review, (106), 309-313. https://www.aeaweb.org/articles?id=10.1257/aer.p20161009

Lambin, J. J. (2014). Rethinking the Market Economy. Symphonya. Emerging Issues in Management (symphonya.unimib.it), (2), 4-15.

http://dx.doi.org/10.4468/2014.2.02lambin 
Leed, E., (1992). The Mind of the Traveler: From Gilgamesh to Global Tourism. New York: Basic Books.

Lieberman, M. D. (2000). Intuition: a social cognitive neuroscience approach. Psychological Bulletin, 126 (1), 109-137. http://dx.doi.org/10.1037/0033-2909.126.1.109

Milosavljevic, M., Cerf, M. (2008). First attention then intention. Insights from computational neuroscience of vision. International Journal of Advertising, 27 (3), 381-398. http://dx.doi.org/ 10.2501/ S0265048708080037

Nikolova, H. D., Inman, J. J. (2015). Healthy Choice: The Effect of Simplified Point-of-Sale Nutritional Information on Consumer Food Choice Behavior. Journal of Marketing Research, 52 (6), 817-835.

Olsen, K., Topsøe-Jensen, H. (ed.) (1973). H.C. Andersens Dagbøger 1825-1875. København: Det Danske Sprog- og Litteraturselskab, (II), 242-243.

Olson, J. C., Jacoby, J. (1972). Cue Utilization in the Quality Perception Process, in Venkatesan M. (ed.) SV - Proceedings Third Annual Conference of the Association for Consumer Research, Chicago: Association for Consumer Research, 167-179.

Pergament, D. (2017). 52 Places to Go in 2017. The New York Times, January 4.

Pernice, K., Whitenton, K., Nielsen, J. (2014). How People Read on the Web: The Eyetracking Evidence. Nielsen Norma Group.

Pine, B. J., Gilmore, J. H. (1999). The experience economy. Boston: Harvard Business School Press.

Reitano, A., Calomino, P. (2008). On the use of physiological tests in consumer research. International Journal of Management Case, 10 (3), 495-504.

https://doi.org/10.5848/APBJ.2008.00072

Reitano, A., Fazio, M. (2014). Valuation of the protection trademarks with eye tracking systems and purchasing decision, in Proceedings Una nueva perspectiva para una nueva recuperación del desarrollo económico. El rol de lo public y lo privado, XXX Encuentro Arethuse, Puerto de Santa Maria, 11-12 septiembre, 294-322.

Reitano, A., Fazio, M. (2015). An eye tracking approach to consumers reaction to olive oil protection brands, in Proceedings Contemporary trends and perspectives in wine and agrifood management, Euromed Academy of Business, EuroMed Press, Lecce, 1516 January, 357-368.

Roberto, C. A., Shivaram, M., Martinez, O., Boles, C., Harris, J. L., Brownell, K. D. (2012). The smart choices front-of-package nutrition label. Influence on perceptions and intake of cereal. Appetite, (58), 651-657. http://dx.doi.org/10.1016/j.appet.2012.01.003

Salama, H. H. (2015). Dubai: An Urbanism Shaped for Global Tourism. Architectural Engineering Technology, 4 (3), 1-4, http://dx.doi.org/10.4172/2168-9717.1000154

Salazar, N. B. (2016). The Local-to-Global Dynamics of World Heritage Interpretation, in Bourdeau, L., Gravari-Barbas, M., Robinson, M. (ed.). World Heritage, Tourism and Identity, . New York: Routledge, 121-130.

Salvioni, D. M. (2016). Hotel Chains and the Sharing Economy in Global Tourism. Symphonya Emerging Issues in Management (symphonya.unimib.it), (1), 31-44.

http://dx.doi.org/10.4468/2016.1.04salvioni

Scott D., Gössling S. (2015). What could the next 40 years hold for global tourism? Tourism Recreation Research, 40 (3), 269-285.

http://dx.doi.org/10.1080/02508281.2015.1075739

Seitz, V. A., Razzouk, N., Triyangkulsri, W. (2007). Factors Influencing the Purchasing Decision Process of Low-Carbohydrate Products. Journal of Food Products Marketing, 13 (4), 23-38. http://dx.doi.org/10.1300/J038v13n04_02 
Špirková, D. (2011). The brownfield reuse of river waterfront in Bratislava, in Tira, M., Ivanička, K., Špirková, D. (ed.). Industrial urban land redevelopment. Milan: Maggioli, 109-116.

Stanovich, K. E., West, R. F. (2000). Individual differences in reasoning: Implications for the rationality debate? Behavioral and Brain Sciences, (23), 645-726.

Teas, R. K., Agarwal, S. (2000). The Effects of Extrinsic Product Cues on Consumers' Perceptions of Quality, Sacrifice and Value. Journal of Academy of Marketing Science, 28 (2), 278-290.

van Herpen, E., Seiss, E., van Trijp, H. C. M. (2012). The role of familiarity in front-of-pack label evaluation and use: A comparison between the United Kingdom and The Netherlands. Food Quality and Preference, 26 (1), 22-34.

http://dx.doi.org/10.1016/j.foodqual.2012.03.003

Zeithaml, V. A. (1988). Consumer Perceptions of Price, Quality and Value: A Means-End Model and Synthesis of Evidence. Journal of Marketing, 52 (3), 2-22.

Zhang, J., Wedel, M., Pieters, R. (2009). Sales effects of attention to feature advertisements: A Bayesian mediation analysis. Journal of Retailing, 46 (5), 669-681.

http://dx.doi.org/10.1509/ jmkr.46.5.669 